\title{
Preliminary results of effect of barley (Hordeum vulgare L.) extract on liver, pancreas, kidneys and cardiac tissues in streptozotocin induced diabetic rats
}

\author{
Mohsen Naseri (1,2,3), Zahra Khalaj Sereshki (4), Behnaz Ghavami (5), Bagher Minaii \\ Zangii (6), Mohammad Kamalinejad (7), Parvaneh Mohseni Moghaddam (8), Majid \\ Asghari (9), Seyed Abbas Hasheminejad (1,2), Fatemeh Emadi (1,2), Farzaneh Ghaffari \\ (10)
}

(1) Traditional Medicine Clinical Trial Research Center, Shahed University, Tehran, Iran; (2) Department of Traditional Persian Medicine, School of Medicine, Shahed University, Tehran, Iran; (3) Hikmat, Islamic and Traditional Medicine Department, The Academy of Medical Sciences, Tehran, Iran; (4) (4)Department of Gynecology, School of Medicine, Yas Hospital, Tehran University of Medical Sciences, Tehran, Iran; (5)Department of Gynecology, School of Medicine, Arash Hospital, Tehran University of Medical Sciences, Tehran, Iran; (6) Department of Histology, School of Medicine, Tehran University of Medical Sciences, Tehran, Iran; (7) School of Pharmacy, Shahid Beheshti University of Medical Sciences, Tehran, Iran; (8) Department of Physiology, Faculty of Medicine, Tehran Medical Sciences, Islamic Azad University, Tehran, Iran, Iran; (9)School of Persian Medicine, Qom University of Medical Sciences, Qom, Iran; (10) School of Traditional Medicine, Shahid Beheshti University of Medical Sciences, Tehran, Iran.

This article is distributed under the terms of the Creative Commons Attribution Noncommercial License (CC BY-NC 4.0) which permits any noncommercial use, distribution, and reproduction in any medium, provided the original author(s) and source are credited.

\begin{abstract}
Diabetes mellitus (DM) and its complications impose a significant burden on patients and the health care system. In the Traditional Persian Medicine (TPM), barley is recommended for treatment of DM. This study sought to assess the effect of barley seed aqueous extract on hepatic, pancreatic, renal and cardiac tissues in normal (non-diabetic) and Streptozotocin-induced diabetic rats. Twenty-one male Wistar rats were randomly divided into diabetic and non-diabetic groups. Diabetes was induced by single intraperitoneal injection of Streptozotocin. After one week, the diabetic and non-diabetic groups were randomly divided into control and barley seed extract subgroups namely $\mathrm{N}$ group (non-diabetic control rats), S group (seed extract treated nondiabetic rats), D group (diabetic control rats) and DS group (seed extract treated diabetic rats). After 6 weeks, all rats were sacrificed for histopathological analysis and specimens were stained routinely for histological studies. The abnormal histological signs significantly decreased in the DS group compared to D group. Also, protective effects of barley seed extract against histopathological changes were seen in $\mathrm{S}$ group compared to $\mathrm{N}$ group.These findings suggest that barley seed extract exerts a protective effect on different tissues in diabetes.
\end{abstract}

Key Words: Barley; diabetes; traditional persian medicine; Streptozotocin; diabetes mellitus.

Eur J Transl Myol 32 (1): 10108, 2022 doi: 10.4081/ejtm.2022.10108

Diabetes mellitus (DM) is a group of common metabolic disorders with the common phenotype of hyperglycemia. This condition can lead to adverse consequences for the patient and impose an heavy burden on the health care system. ${ }^{1}$ DM type 1 is a form of DM that results from destruction of beta cells in the pancreas which leads to absolute insulin insufficiency. ${ }^{2}$ It is responsible for approximately $5-10 \%$ of all cases of diabetes; however, its incidence is increasing worldwide and it has serious short-term and long-term complications. ${ }^{3}$ Some tissue-specific injuries also occur. In the liver histological changes can vary from steatosis to steatohepatitis and liver fibrosis. ${ }^{4,5} \mathrm{DM}$ contributes greatly to mortality due to the high incidence of nephropathy leading to end stage renal disease. Indeed it is a major cause of dialysis and kidney transplantation. ${ }^{6}$ Diabetes facilitates pathological changes in the cardiovascular system of these patients, increasing risks 
of cardiovascular complications (acute coronary syndromes, stroke, heart failure and arrhythmias). ${ }^{7}$ High cost of treatment and side effects of medications, namely increased risk of cardiovascular diseases, hypoglycemia and weight gain, are among the common complications of pharmacologic therapies. ${ }^{8-11}$

Traditional Persian Medicine (TPM) has gained attention in the recent years and some of the new medications originate from traditional medicine. ${ }^{12,13} \mathrm{TPM}$, one of the traditional healthcare systems, has been practiced since thousand years. ${ }^{14-16}$ Their theoretical backgrounds may offer the bases for development of new drugs. ${ }^{17-19}$

According to Persian traditional medicine barley grain (Hordeum vulgare L.) is recommended for treatment of diabetes. Outstanding books such as Al-Havi (Liber continents; written by Rhazes in $10^{\text {th }}$ century AD) ${ }^{20}$ and Al-Qanun fi al-Tib (Canon of Medicine; written by Avicenna in $1025 \mathrm{AD})^{21}$ recommended the use of medicinal beer to quench thirst. This drink is made by boiling barley in water and is claimed to be beneficial for diabetic patients.

Modern studies also shows positive effects of drinking barley aqueous extract. In a study by Naseri et al. in diabetic rats, they caused a significant reduction in serum glucose level after 4 weeks of consumption. ${ }^{22}$ Furthermore, antioxidant properties of phenolic compounds in barley add to its nutritional value. ${ }^{23-25}$ Antioxidants play an important role in prevention of chronic diseases by elimination of reactive oxygen species (ROS). It appears that the antioxidant properties of barley are related to the flavan-3-ol, hydroxycinnamic acid derivatives and flavonols. ${ }^{26}$

Considering increased amount of free radicals in diabetic patients, ${ }^{27-29}$ and presence of abundant antioxidants in barley, ${ }^{23-26}$ this study was designed to evaluate the effect of barley seed extract on liver, pancreas, kidney and heart in control and diabetic rats.

\section{Materials and Methods}

\section{Extract Preparation}

Ready for harvest barley grains 4 months after sowing were purchased from an agricultural farm in Mehrshahr Karaj. After ensuring the apparent health of grains the voucher specimen was deposited at herbarium of School of Shahid Beheshti University with voucher number 580. The method of extract preparation in this study was adapted from the traditional medicine instructions on how to prepare a medicinal beer. ${ }^{20,30-33}$ For extract preparation, $500 \mathrm{~g}$ barley seeds in $1000 \mathrm{ml}$ of distilled water were heated in a beaker. After the contents of the beaker were boiled, the boiling process were continued for 10 minutes and after cooling down, were filtered using a laboratory filter paper. The obtained solution was concentrated, weighed $97 \mathrm{~g}(19.4 \%)$ and stored in a freezer at $-20^{\circ} \mathrm{C}(1 \%$, weight per weight, W/W). Barely aqueous extract was mixed with standard food to prepare the food for the treatment groups.

\section{Total phenolic content of barley extract}

Total phenolic content of barely aqueous extract was detected using spectrophotometric method. To determine phenolic concentration, the reaction mixture was use by mixing $1 \mathrm{ml}$ barely aqueous extract ( $2 \mathrm{mg} / \mathrm{ml})$, FolinCiocalteu's reagent $10 \%(5 \mathrm{ml})$ and $4 \mathrm{ml} \mathrm{NaHCO} 3$ (7.5 $\mathrm{mg} / \mathrm{ml}$ ). Blank was prepared using water without extract. Samples were incubated at room temperature for $30 \mathrm{~min}$. The absorbance was detected using spectrophotometer at $\lambda \max =765 \mathrm{~nm}$. All samples for analysis were prepared in triplicate. The same procedure was repeated for the gallic acid as standard in concentrations of 10, 20, 40, 80 $\mu \mathrm{g} / \mathrm{ml}$. To achieve phenolic concentration the gallic acid (GA) calibration curve based on the detected absorbance was construed. ${ }^{34,35}$

\section{Animal Ethics}

All experimental protocols were approved by the local animal care committee in accordance with Tehran University of Medical Sciences guidelines and Use of Laboratory Animals of the National Institute of Health Bethesda United State of America for the care and use of laboratory animals. ${ }^{36}$

\section{Animals}

This study was conducted on 21 white male Wistar rats weighing 200 to $300 \mathrm{~g}$ in the age range of 6 to 8 months. The rats had been transferred from the Razi Institute to the animal room of the School of Medicine, Shahed University, 2 weeks earlier. During the study, animals had free access to water and food. Animals were fasted for $12 \mathrm{~h}$ and weighed using a digital scale. Blood was taken from the caudal artery for the measurement of fasted blood glucose level. ${ }^{37}$ All study phases followed the guide for the care and use of laboratory animals. ${ }^{38}$

\section{Diabetes induction}

For induction of type I diabetes, 7 rats were fasted for 12h. Streptozotocin powder (Sigma, USA) was completely dissolved in freshly prepared 0.05 molar citrate buffered solution with a $\mathrm{pH}$ of $4.5^{39}$. The final concentration of Streptozotocin in citrate buffered solution was $13.5 \mathrm{mg} / \mathrm{ml}$. In less than $15 \mathrm{~min},{ }^{40}$ the prepared solution was intraperitoneally injected to rats as single dose using an insulin syringe in such a way that the pure dose of injected Streptozotocin was $45 \mathrm{mg} / \mathrm{kg}$ for each rat. ${ }^{39,41-43}$ After one week, diabetic rats were weighed, fasted. Symptoms of diabetes including weight loss, polydipsia and polyuria were seen in the diabetic animals. Blood was taken and fasted blood glucose level was assessed to confirm the induction of diabetes. Fasted serum glucose level over $200 \mathrm{mg} / \mathrm{dL}$ was considered as the criterion for diabetes. ${ }^{44}$

\section{Conduction of study}

Two weeks' time was allowed for rats to become familiar with the environment and the eating habits. Male Wistar rats were randomly divided into 2 groups of 14 nondiabetic and 7 diabetic rats. In the diabetic rats, diabetes 


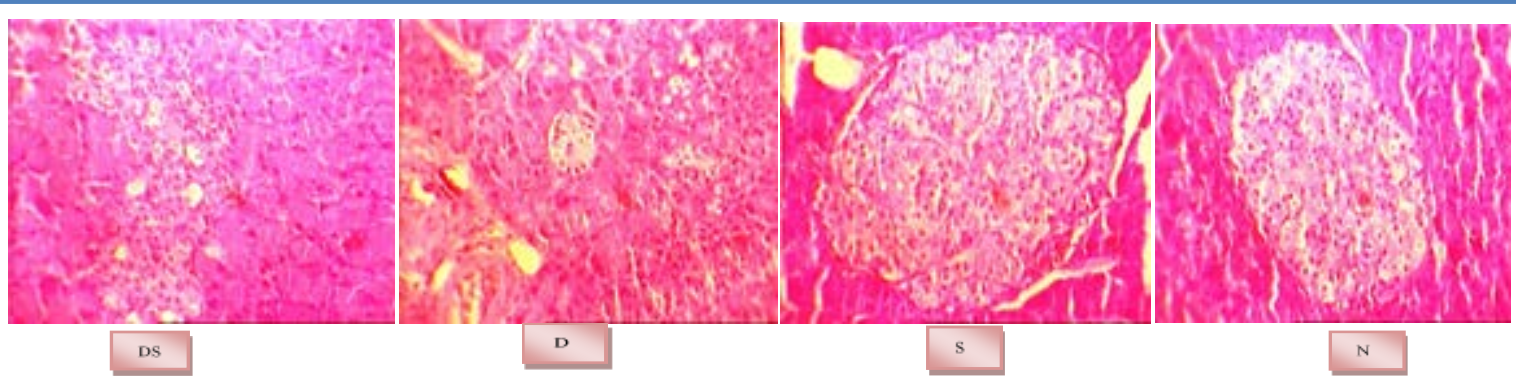

Fig 1. Histological views of the pancreas. N: Non-diabetic control group, S: Non-diabetic group receiving barley extract, D: Diabetic control group and DS: Diabetic group receiving barley extract.

was induced by single dose intraperitoneal injection of 45 $\mathrm{mg} / \mathrm{kg}$ Streptozotocin. Fasted serum glucose level of rats in the diabetic group was measured one week later and induction of diabetes was confirmed by a serum glucose level over $200 \mathrm{mg} / \mathrm{dL}$. Diabetic and non-diabetic groups were then randomly divided into 2 subgroups as follows:

1. Non-diabetic control group $(\mathrm{N})$ with 7 rats

2. Non-diabetic group receiving barley extract (S) with 7 rats

3. Diabetic control group (D) with 4 rats

4. Diabetic group receiving barley extract (DS) with 3 rats

It should be mentioned that the control groups received regular food (Pars, Iran); while the test groups received a combination of extract and the standard food. Two weeks after the completion of the 4-week experiment, animals were sacrificed and their liver, pancreas, kidneys and heart were removed and used for histological studies. For this purpose, organs (tissues) were fixed in $10 \%$ formaldehyde for $24 \mathrm{~h}$ and dehydrated using sequential ethanol concentrations. Specimens were then embedded in paraffin blocks and cut into $4-5 \mu \mathrm{m}$ thick sections for staining. Then haematoxylin-eosin staining (H\&E) was done. After staining, specimens were histologically evaluated under a light microscope. For determination of tissue changes, a 0-2 scoring system was used compared to the control group. ${ }^{45-47}$

\section{Results}

Total Phenols contents of barely aqueous extract was determined as $3.61 \pm 7 \mathrm{mg} / \mathrm{g}$ GA equivalent using the spectrophotometric method. In histomorphological study of pancreas in the diabetic group (D), atrophy of the islets of Langerhans, reduction in their size and number, significant reduction in cell differentiation, destruction and necrosis of beta cells and infiltration of mononuclear cells in the islets of Langerhans were observed. Such abnormal histological changes significantly decreased in the diabetic group that consumed barley extract (DS) compared to the diabetic control group. The non-diabetic group receiving barley extract $(S)$ showed healthier pancreatic tissue compared to the non-diabetic control group $(\mathrm{N})$. Histological evaluation of pancreatic tissue revealed that the $\mathrm{S}$ group had increased number of islets of Langerhans, increased number of undifferentiated cells around the islets of Langerhans and increased capillaries (Figure 1 and Table 1).

Histomorphological study of the liver: In the diabetic control group (D), fatty liver, local infiltration of mononuclear cells, increased number of Kupffer cells, fibrosis of the portal spaces and sinusoidal dilatation and hemorrhage were seen. Such abnormal histological changes showed a significant reduction in the DS group compared to D group. The comparison of $\mathrm{N}$ and $\mathrm{S}$ groups

Table 1. Comparison of the different characteristics of pancreatic tissues in the understudy groups after hematoxylin and eosin staining.

\begin{tabular}{|c|c|c|c|c|c|c|c|}
\hline $\begin{array}{l}\text { Pancreatic } \\
\text { tissue }\end{array}$ & $\begin{array}{l}\text { Reduction } \\
\text { of Island } \\
\text { size }\end{array}$ & $\begin{array}{c}\text { Reduction } \\
\text { of Island } \\
\text { number }\end{array}$ & $\begin{array}{l}\text { Reduction of } \\
\text { the number of } \\
\text { granules in } \\
\text { beta cells }\end{array}$ & $\begin{array}{l}\text { Increment } \\
\text { of capillary } \\
\text { in Island }\end{array}$ & $\begin{array}{c}\text { Increase in } \\
\text { differentiation }\end{array}$ & $\begin{array}{l}\text { Reduction in } \\
\text { differentiation }\end{array}$ & $\begin{array}{c}\text { Infiltration of } \\
\text { Mononuclear } \\
\text { cells }\end{array}$ \\
\hline $\mathrm{N}$ & - & - & - & - & - & - & + \\
\hline $\mathrm{D}$ & + & + & + & - & - & ++ & ++ \\
\hline DS & + & + & + & + & + & - & + \\
\hline S & - & - & - & ++ & ++ & - & + \\
\hline
\end{tabular}

The scores were calculated by a pathologist from zero to 2. $\mathrm{N}$ : Non-diabetic control group, S: Non-diabetic group receiving barley extract, D: Diabetic control group, and DS: Diabetic group receiving barley extract. 
Table 2. Comparison of different characteristics of liver tissue in the understudy groups after H \& E staining.

\begin{tabular}{|c|c|c|c|c|c|c|}
\hline $\begin{array}{c}\text { Liver } \\
\text { tissue }\end{array}$ & $\begin{array}{c}\text { Fatty } \\
\text { liver }\end{array}$ & Congestion & $\begin{array}{c}\text { Infiltration of } \\
\text { Mononuclear } \\
\text { in Lobule }\end{array}$ & $\begin{array}{c}\text { Kupffer cell } \\
\text { Hyperplasia }\end{array}$ & $\begin{array}{c}\text { Fibrosis in } \\
\text { portal space }\end{array}$ & $\begin{array}{c}\text { Hemorrhage in } \\
\text { Sinusoidal } \\
\text { dilation }\end{array}$ \\
\hline N & - & - & + & - & - & - \\
\hline D & + & + & + & + & + & + \\
\hline DS & - & - & ++ & - & - & - \\
\hline S & - & - & + & - & - & - \\
\hline
\end{tabular}

The scores were calculated by a pathologist from zero to 2. N: Non-diabetic control group, S: Non-diabetic group receiving barley extract, D: Diabetic control group, and DS: Diabetic group receiving barley extract.

revealed that these two groups had similar histology and a normal liver structure (Table 2).

Histomorphological study of the kidneys: In group D, bleeding in the cortex of kidneys, hyperemia, glomeruli to capsule adhesion, increased number of glomerular cells, increased thickness of glomerular endothelium, destruction of distal convoluted tubule (DCT) and proximal convoluted tubule (PCT) epithelial cells and infiltration of mononuclear cells were seen. The comparison of D and DS groups revealed that DS group had healthier organs. Groups $\mathrm{N}$ and $\mathrm{S}$ were found to be histologically similar (Table 3).

Histomorphological study of the heart: In group D, atrophy of the cardiac muscle cells in the apex of the heart, hypertrophy of the atrial cardiac muscle cells, hyperemia, bleeding, hypochromic atrial muscle cells and infiltration of mononuclear cells were noted. Group DS had healthier tissues than group D. Groups N and S were histologically similar (Table 4).

\section{Discussion}

DM leads to severe metabolic imbalance and changes in tissues. Oxidative stress seems to play an important role in this imbalance. Diabetic animal models show significant oxidative stress due to chronic hyperglycemia that decreasing the antioxidant defense system increases the production of free radicals. ${ }^{48,49}$ Free radicals play an important role in the DM complications. ${ }^{50}$ Plants are among the antioxidant sources, specifically grains due to their phenolic compounds have antioxidant properties. ${ }^{25}$ Grains of barley are a rich source of phenolic compounds. $^{24}$ Persian traditional medicine has emphasized the beneficial effects of barley on DM. The efficacy of medicinal beer, made by boiling barley in water, for treatment of DM has also been documented. ${ }^{20,21}$ Furthermore, in a study conducted in 2010 by Naseri et al., ${ }^{22}$ it was demonstrated that barley aqueous extract decreased hyperglycemia in diabetic rats. In the present study, we evaluated the effect of barley extract on pancreatic, hepatic, renal and cardiac tissues in Streptozotocin-induced diabetic rats. The data show that barley aqueous extract significantly decreases the histological signs of disease in the diabetic group receiving the extract compared to the diabetic control group. Also, our findings show that the pancreatic tissue in the non-diabetic group receiving the extract seemed healthier histologically compared to the non-diabetic control group. Our preliminary data may indicate the protective and therapeutic effects of barley aqueous extract in diabetic rats. Evaluation of oxidative stress

Table 3. Comparison of different characteristics of renal tissues in the understudy groups after H \& E staining.

\begin{tabular}{|c|c|c|c|c|c|c|c|}
\hline $\begin{array}{c}\text { Renal } \\
\text { tissue }\end{array}$ & $\begin{array}{c}\text { Hemorrhage } \\
\text { in cortex }\end{array}$ & Congestion & $\begin{array}{c}\text { Glomeruli to } \\
\text { capsule } \\
\text { adhesion }\end{array}$ & $\begin{array}{c}\text { Hyperplasia of } \\
\text { internal } \\
\text { mesangial }\end{array}$ & $\begin{array}{c}\text { Thickness of } \\
\text { glomerular } \\
\text { endothelium }\end{array}$ & $\begin{array}{c}\text { Degeneration of } \\
\text { PCT \& DCT } \\
\text { Epithelia }\end{array}$ & $\begin{array}{c}\text { Infiltration of } \\
\text { mononuclear } \\
\text { cells }\end{array}$ \\
\hline N & - & - & - & - & - & - & + \\
\hline D & ++ & + & ++ & ++ & ++ & ++ & ++ \\
\hline DS & + & + & + & + & + & + & + \\
\hline S & - & - & - & - & - & + \\
\hline
\end{tabular}

The scores were calculated by a pathologist from zero to 2. $N$ : Non-diabetic control group, S: Non-diabetic group receiving barley extract, D: Diabetic control group, and DS: Diabetic group receiving barley extract. 
Table 4. Comparison of different characteristics of liver tissue in the understudy groups after $H$ \& E staining.

\begin{tabular}{|c|c|c|c|c|c|c|}
\hline $\begin{array}{c}\text { Cardiac } \\
\text { tissue }\end{array}$ & $\begin{array}{c}\text { Atrophy } \\
\text { in apex }\end{array}$ & $\begin{array}{c}\text { Hypertrophy in } \\
\text { atrium }\end{array}$ & Congestion & Hemorrhage & $\begin{array}{c}\text { Pale of } \\
\text { cytoplasm }\end{array}$ & $\begin{array}{c}\text { Infiltration of } \\
\text { mononuclear cells }\end{array}$ \\
\hline N & - & - & - & - & - & + \\
\hline D & + & + & + & ++ & + & + \\
\hline DS & - & - & - & - & - & + \\
\hline S & - & - & - & - & - & + \\
\hline
\end{tabular}

The scores were calculated by a pathologist from zero to 2. N: Non-diabetic control group, S: Non-diabetic group receiving barley extract, D: Diabetic control group, and DS: Diabetic group receiving barley extract.

markers in diabetic rats indicated that ROS, increased in the islets of Langerhans. ${ }^{29}$ Chanpoo et al., ${ }^{28}$ in a study in 2010 evaluated the effect of consumption of curcumin on the pancreatic tissue in rats and reported the infiltration of mononuclear cells in the islets of Langerhans and reduction in size and number of islets in the diabetic group. Our preliminary data are in accord with those findings. They also concluded that curcumin had antioxidant properties and in the diabetic groups resulted in increase of pancreatic islets after 12 weeks. ${ }^{28}$ Thymoquinone is among the main ingredients of Nigella sativa plant and has a high antioxidant potential. By reducing oxidative stress, it preserve the islets of Langerhans and the beta cells. ${ }^{51}$ Infiltration of mononuclear cells and sinusoidal dilatation as well as signs of tissue necrosis in the liver of diabetic rats reported by Maisaa et al., ${ }^{52}$ are also seen in our study. They evaluated the effect of Trifolium alexandrinum flower aqueous solution on the hepatic tissue of diabetic rats and showed that this extract may improve the histological changes in diabetic rats. This function may be attributed to the high flavonoid content acting as antioxidant. ${ }^{4}$ Moreover, in our study, adhesion of glomeruli to capsule, increased number of glomeruli cells, thickening of the glomerular endothelium and destruction of epithelial cells in DCT and PCT were seen in the renal tissue of diabetic group. All these signs were also reported by Gross et al., in their study on the renal tissue of diabetic rats. ${ }^{53}$ Many similar studies have investigated the effects of different medicinal plants with antioxidant properties on the diabetic renal tissues with significant therapeutic effects. ${ }^{54,55}$ Histological analysis of diabetic cardiac tissue revealed changes in the myocardial cells, bleeding in the cardiac tissue, hypochromic atrial muscle cells and infiltration of mononuclear cells. Other studies have also demonstrated that cardiac ischemia is more common and more severe in diabetic patients and DM can cause significant cardiovascular diseases. $5^{6}$ Studies have reported that oxidative stress in DM is the main cause of cardiovascular diseases. ${ }^{57}$

Based on our preliminary data, we may conclude that barley aqueous extract has beneficial effects on prevention of tissue changes in DM. This property is probably due to its antioxidant characteristics, but further studies are required to confirm by quantitative statistical analyses the here reported qualitative data and precisely determine the active ingredients of barley aqueous extract.

\section{List of acronyms}

AD: Anno Domini

DCT - destruction of distal convoluted tubule

DM - diabetes mellitus

DS - diabetic group that consumed barley extract

GA - gallic acid

$\mathrm{N}$ - non-diabetic control group

PCT - proximal convoluted tubule

ROS - Reactive Oxygen Species

$\mathrm{S}$ - non-diabetic group receiving barley extract

TPM - Traditional Persian Medicine

W/W - weight per weight

\section{Contributions of Authors}

All authors made substantial contributions to the conception, design, and analysis and interpretation of data for this work. All authors contributed substantially to the drafting and critical revision of the manuscript, provided final approval of the version submitted, and agree to be held accountable for all aspects of the work.

\section{Acknowledgments}

The authors would like to thank the Medicinal Plant Research Center and School of Medicine of Shahed University for their sincere cooperation in the conduction of this research project.

\section{Funding}

This research received no external funding

\section{Conflict of Interest}

The authors declare no conflict of interests.

\section{Ethical Publication Statement}

We confirm that we have read the Journal's position on issues involved in ethical publication and affirm that this report is consistent with those guidelines. 


\section{Corresponding Author}

Dr. Farzaneh Ghaffari. School of Traditional Medicine, Shahid Beheshti University of Medical Sciences, Tehran, Iran. Tel: +989123881874

ORCID iD: 0000-0002-5424-4348

E-mail: f_ghaffari@sbmu.ac.ir

E-mails and ORCID iD of co-authors

Mohsen Naseri:naseri@shahed.ac.ir

ORCID iD: . 0000-0001-9239-768X

Zahra Khalaj Sereshki:dr.zahrakhalaj@gmail.com

ORCID iD: 0000-0002-7208-7964

Behnaz Ghavami: Email: Behnaz.ghavami@gmail.com

ORCID iD: 0000-0002-5192-1745

Bagher Minaii Zangii: minaezb@sina.tums.ac.ir

ORCID iD: 0000-0001-5064-2448

Mohammad Kamalinejad: mkamalinejad@yahoo.com

ORCID iD: 0000-0002-5946-4913

Parvaneh Mohseni Moghaddam:

p.mohseni@iautmu.tums.ac.ir

ORCID iD: 0000-0002-0608-2305

Majid Asghari: asghari.rall@gmail.com

ORCID iD: 0000-0003-1155-3172

Seyed Abbas Hashemi Nejad:

abbas.hasheminejad@shahed.ac.ir

ORCID iD: 0000-0001-9635-7669

Fatemeh Emadi: fatemeh12emadi@yahoo.com

ORCID iD: 0000-0002-5053-4591

\section{References}

1. Longo DL, Fauci AS, Kasper DL, Hauser SL, Jameson JL, Loscalzo J. Harrison's Principles of Internal Medicine. 19th ed. McGraw-Hill Medical, 2014.

2. Simmons KM, Michels AW. Type 1 diabetes: A predictable disease. World J Diabetes. 2015 Apr 15;6(3):380-90. doi: 10.4239/wjd.v6.i3.380.

3. Daneman D. Type 1 diabetes. Lancet. 2006 Mar 11;367(9513):847-58. doi: 10.1016/S01406736(06)68341-4.

4. AlRawi MM. Effect of Trifolium sp. flowers extracts on the status of liver histology of streptozotocin-induced diabetic rats. Saudi J Biol Sci. 2007;14(1):21-8.

5. Bilal HM, Riaz F, Munir K, Saqib A, Sarwar MR. Histological changes in the liver of diabetic rats: A review of pathogenesis of nonalcoholic fatty liver disease in type 1 diabetes mellitus. Cogent Medicine. 2016;3(1):1275415.

6. Vallon V, Thomson SC. Renal function in diabetic disease models: the tubular system in the pathophysiology of the diabetic kidney. Annu Rev Physiol. 2012;74:351-75. doi: 10.1146/annurevphysiol-020911-153333.

7. Hess K, Marx N, Lehrke M. Cardiovascular disease and diabetes: the vulnerable patient. Eur Heart J. Suppl. 2012;14(suppl B):B4-B13.
8. Carver C. Insulin treatment and the problem of weight gain in type 2 diabetes. Diabetes Educ. 2006 Nov-Dec;32(6):910-7. doi: 10.1177/014572170629 4259.

9. Daisy P, Rajathi M. Hypoglycemic effects of Clitoria ternatea Linn.(Fabaceae) in alloxaninduced diabetes in rats. Trop $\mathrm{J}$ Pharm Res. 2009;8(5).

10. Funnell MM. Overcoming barriers to the initiation of insulin therapy. Clin Diabetes. 2007;25(1):36-8.

11. Ghoraishian S.M. The effect of hazel-leaf decoction on blood glucose reduction in the diabetic rats. World J Med Sci. 2006; 1 (2): 144-146.

12. Moosavyzadeh A, Mokri, A, Ghaffari F, Faghihzadeh S,Azizi H, Jafari Hajati R, Naseri M. Hab-o Shefa, a Persian Medicine Compound for Maintenance Treatment of Opioid Dependence: Randomized Placebo-Controlled Clinical Trial. Journal of Alternative and Complementary Medicine. 2020; 26(5): 376-383.

13. Hajiheydari MR, Yarmohammadi ME, Izadi $P$, Jafari F, Emadi F, Emaratkar E. Abtahi SHR, Zargaran A, Naseri M. Effect of Nepeta bracteata Benth. on allergic rhinitis symptoms: A randomized double-blind. clinical trial Journal of Research in Medical Sciences. 2017, 22(11), 128.

14. Ghaffari F, Naseri M, Movahhed M, Zargaran A. Spinal Traumas and their Treatments According to Avicenna's Canon of Medicine. World Neurosurg. 2015, 84, 173-7.

15. Ghaffari F, Naseri M, Hajati R J \& Zargaran A. Rhazes, a pioneer in contribution to trials in medical practice. AMHA-Acta medico-historica Adriatica. 2017; 15(2), 261-270.

16. Ghaffari F, Naseri M, Asghari M, Naseri V. AbulHasan al-Tabari: a review of his views and works. Arch Iran Med. 2014;17(4):299-301.

17. Ahmadi A, Mohagheghi M, Karimi M, Golestanha SA, Naseri M. Faghihzadeh, S. Habibi, G. Therapeutic effects of HESA-A in patients with end-stage metastatic cancers . Integr Cancer Ther. 2010;9(1):32-35.

18. Goshtasebi A, Mazari Z, Behboudi Gandevani S, Naseri M. Anti-hemorrhagic activity of Punica granatum L. flower (Persian Golnar) against heavy menstrual bleeding of endometrial origin: A double-blind, randomized controlled trial. Medical Journal of the Islamic Republic of Iran. 2015; 29 (1), 325-332.

19. Babaeian M, Naseri M, Kamalinejad M, Ghaffari F, Emadi F, Feizi A, Park J W. The efficacy of mentha longifolia in the treatment of patients with postprandial distress syndrome: A double-blind, randomized clinical trial. Iranian Red Crescent Medical Journal. 2017, 19(2); e34538.

20. Ibn Sina AAH. Al-Qanun fi al-Tibb. 1st ed. Beirut, Lebanon: Alamy Le- Al-Matbooat institute, 2005. 
21. Rhazes M. Alhavi fi al-Tibb (Liber continents). 1st ed. Beirut, Lebanon: Alamy Le- Al-Matbooat institute, 2006.

22. Naseri M, Sereshki Z, Ghavami B, Nejad M, Naderi G, Faghihzadeh S. Effect of barley (Hordeum vulgare L.) seed extract on fasting serum glucose level in streptozotocin induced diabetic rats. J Med Plants. 2010;9(34).

23. Bonoli M, Verardo V, Marconi E, Caboni MF. Antioxidant phenols in barley (Hordeum vulgare L.) flour: comparative spectrophotometric study among extraction methods of free and bound phenolic compounds. J Agric Food Chem. 2004 Aug 11;52(16):5195-200. doi: 10.1021/jf040075c.

24. Gerhäuser C. Beer constituents as potential cancer chemopreventive agents. Eur J Cancer. 2005 Sep;41(13):1941-54. doi: 10.1016/j.ejca.2005.04. 012.

25. Hollman PCH. Evidence for health benefits of plant phenols: local or systemic effects? J Sci Food Agr. 2001;81(9):842-52.

26. Maillard M-N, Soum M-H, Boivin P, Berset C. Antioxidant activity of barley and malt: relationship with phenolic content. LWT - Food Sci Technol. 1996;29(3):238-44.

27 Baynes JW. Role of oxidative stress in development of complications in diabetes. Diabetes. 1991 Apr;40(4):405-12. doi: 10.2337/diab.40.4.405.

28. Chanpoo M, Petchpiboonthai H, Panyarachun B, Anupunpisit V. Effect of curcumin in the amelioration of pancreatic islets in streptozotocininduced diabetic mice. J Med Assoc Thai. 2010 Nov;93 Suppl 6:S152-9.

29. Ihara Y, Toyokuni S, Uchida K, Odaka H, Tanaka $\mathrm{T}$, Ikeda $\mathrm{H}$, Hiai $\mathrm{H}$, Seino $\mathrm{Y}$, Yamada $\mathrm{Y}$. Hyperglycemia causes oxidative stress in pancreatic beta-cells of GK rats, a model of type 2 diabetes. Diabetes. 1999 Apr;48(4):927-32. doi: 10.2337/diabetes.48.4.927.

30. Mirheydar H. Herbal sciences. 4th ed. Tehran, Iran: Center of Islamic Culture Distribution, 2001.

31. Nazemateba A. Pezeshki Nameh. 1st ed. Tehran, Iran: Kayam bookstore, 1899.

32. Naseri M. Maintaining Health In the viewpoint of Traditional Iranian Medicine (2nd Edition), 2021, 24.

33. Azam M. Mohiteazam. 1st ed. Tehran, Iran: Center of Medical History, Islamic and Complementary Medicine Studies-Iran Medical University, 2004.

34. Marinova D, Ribarova F, Atanassova M. Total phenolics and total flavonoids in Bulgarian fruits and vegetables. J University Chem. Technol and metallurgy. 2005;40(3):255-60.

35. Hosseini Yekta N, Roohany Y, Emadi F, Faghihzadeh S, Naseri M, Heydarirad G, Babaeian M, Vaez Mahdavi MR. Effects of an Herbal Medicine on Relieving Disability and Pain due to
Chronic Low Back Pain (LBP). Biological Forum. 2015; 7 (2), 138-141.

36. Gad SC. Animal models in toxicology. 2nd ed. CRC Press, 2006.

37. Du S, Wu H, Xu X, Meng Y, Xia F, Zhai H, Lu Y. Tracing fasting glucose fluxes with unstressed catheter approach in streptozotocin induced diabetic rats. J Diabetes Res. 2014;2014:743798. doi: 10.1155/2014/743798. Epub 2014 Mar 17.

38 National Research Council. Guide for the care and use of laboratory animals. National Academies Press, 2010.

39. Latha M, Pari L. Preventive effects of Cassia auriculata L. flowers on brain lipid peroxidation in rats treated with streptozotocin. Mol Cell Biochem. 2003 Jan;243(1-2):23-8. doi: 10.1023/a:10216973 11150

40. Feldman E. Animal Models of Diabetic Complications Consortium Protocols, University of Michigan (U01 DK60994). 2005.

41. Kamalakkanan N, Rajadurai M, Prince PS. Effect of Aegle marmelos fruits on normal and streptozotocin-diabetic Wistar rats. J Med Food. 2003 Summer;6(2):93-8. doi: 10.1089/109662 003322233486 .

42. Kamalakkannan N, Stanely Mainzen Prince P. Antihyperlipidaemic effect of Aegle marmelos fruit extract in streptozotocin-induced diabetes in rats. $\mathrm{J}$ Sci Food Agr. 2005;85(4):569-73.

43. Ozansoy G, Akin FB. Effects of gemfibrozil treatment on vascular reactivity of streptozotocindiabetic rat aorta. J Pharm Pharmacol. 2004 Feb;56(2):241-6. doi: 10.1211/0022357022737.

44. Xue WL, Li XS, Zhang J, Liu YH, Wang ZL, Zhang RJ. Effect of Trigonella foenum-graecum (fenugreek) extract on blood glucose, blood lipid and hemorheological properties in streptozotocininduced diabetic rats. Asia Pac J Clin Nutr. 2007;16 Suppl 1:422-6.

45. Aghazadeh S, Azarnia M, Shirazi A, Mahdavi SR, Zangii BM. Melatonin as a protective agent in spinal cord damage after gamma irradiation. Rep Pract Oncol Radiother. 2007;12(2):95-9.

46. Mahdavi SR, Shirazi A, Minaee B, Nikoofar A, Mirzaee HR. Long-term changes of prostacyclin secretion in radiation-induced myelopathy. Rep Pract Oncol Radiother. 2006;11(6):273-9.

47. Pournourmohammadi S, Ostad SN, Azizi E, Ghahremani MH, Farzami B, Minaie B, et al. Induction of insulin resistance by malathion: evidence for disrupted islets cells metabolism and mitochondrial dysfunction. Pest Biochem Physiol. 2007;88(3):346-52.

48. Baynes JW, Thorpe SR. The role of oxidative stress in diabetic complications. Curr Opin Endocrinol Diabetes Obes. 1996;3(4):277-84.

49. Pan HZ, Zhang L, Guo MY, Sui H, Li H, Wu WH, Qu NQ, Liang MH, Chang D. The oxidative stress 
status in diabetes mellitus and diabetic nephropathy. Acta Diabetol. 2010 Dec;47 Suppl 1:71-6. doi: 10.1007/s00592-009-0128-1. Epub 2009 May 28.

50. Mohamed AK, Bierhaus A, Schiekofer S, Tritschler $\mathrm{H}$, Ziegler R, Nawroth PP. The role of oxidative stress and NF-kappaB activation in late diabetic complications. Biofactors. 1999;10(2-3):157-67. doi: 10.1002/biof.5520100211.

51. Kanter M. Protective effects of thymoquinone on $\beta$ cell damage in streptozotocin-induced diabetic rats. Tıp Araştırmaları Dergisi. 2009;7(2):64-70.

52. Maisaa MA, Effect of Trifolium sp. Flowers extracts on the Status of Liver Histology of Streptozotocin-induced Diabetic Rats. 2007; Saudi Journal of Biological Sciences. 14(1); 21-28.

53. Gross ML, Ritz E, Schoof A, Adamczak M, Koch A, Tulp O, Parkman A, El-Shakmak A, Szabo A, Amann K. Comparison of renal morphology in the Streptozotocin and the SHR/N-cp models of diabetes. Lab Invest. 2004 Apr;84(4):452-64. doi: 10.1038/labinvest.3700052.

54. Liu IM, Tzeng TF, Liou SS, Chang CJ. The amelioration of streptozotocin diabetes-induced renal damage by Wu-Ling-San (Hoelen Five Herb Formula), a traditional Chinese prescription. J Ethnopharmacol. 2009 Jul 15;124(2):211-8. doi: 10.1016/j.jep.2009.04.021. Epub 2009 May 3.

55. Zhao R, Li QW, Li J, Zhang T. Protective effect of Lycium barbarum polysaccharide 4 on kidneys in streptozotocin-induced diabetic rats. Can J Physiol Pharmacol. 2009 Sep;87(9):711-9. doi: 10.1139/y09-068.

56. Kannel WB, McGee DL. Diabetes and cardiovascular disease. The Framingham study. JAMA. 1979 May 11;241(19):2035-8. doi: 10.1001/jama.241.19.2035.

57. Muruganandan S, Gupta S, Kataria M, Lal J, Gupta PK. Mangiferin protects the streptozotocin-induced oxidative damage to cardiac and renal tissues in rats. Toxicology. 2002 Jul 15;176(3):165-73. doi: 10.1016/s0300-483x(02)00069-0.

Submission: September 12, 2021

Revision received: October 11, 2021 Accepted for publication: October 14, 2021 